\title{
Mit Liv og Levned.
}

\author{
Af H. H. Steensvang.
}

I.

\section{Indledning.}

Da den forhenværende Gaardmand Hans Hansen Steensvang i Aaret 1862 sænkedes i Graven, gav Pastor Mørk-Hansen i Felsted ham følgende Eftermæle i Kirkebogen: "Han har fort et bevæget og eventyrligt Liv, blev overbevist om at have deltaget $i$ at forfierdige og udgive falske Bankosedler, dømtes til Slaveri, men flygtede for Øvrigheden, brød ud af Arresten $i$ Odense og holdt sig $i$ lang Tid skjult $i$ en Hule paa sin Mark. Ved Krigens Udbrud blev han (som dansk Spion) fængslet i Tønder, anstillede sig vanvittig og blev omsider fri. Kongen benaadede lıam aldeles - -

Disse Ord kan være Forklaring nok for, at $" S \mathrm{Sdj}$. Aarbøger" i nærværende Halvbind vil lade denne Mand fortælle om sit "bevægede og eventyrlige« Liv og Levned, om sine Iagttagelser og Tanker. Selvbiografier har i Dag en stor Læserkreds. Det er laade interessant og lærerigt at følge et Menneske fra Barndomshjemmet til dets sidste Hvilested og at se de skiftende Tiders Tildragelser og Meninger genspejle sig i et enkelt Menneskesind. Særlig gælder dette, naar en Mand har oplevet saa meget som Hans Hansen Steensvang. Han kan fortælle om Spanioler, Kosakker og Insurgenter, om trange Kaar og Opgangstider, om Fængsel, Flugt, Fredloshed og Forfølgelser, om Rejser til København og Hamborg, og han iagttager og fortæller godt.

Det var et ejendommeligt Broderpar, som i Begyndelsen af det 19. Aarh. opvoksede paa Gaarden Steensvang i Felsted Sogn, ved Landevejen Aaben- 
raa-Felsted-Graasten. Fra Faderen havde de arvet ualmindelige Legemskræfter, fra Moderen, der var en Søster til den matematikkyndige Bonde Jørgen Hansen i Slyngsten (se Sdj. Aarb. 1909), en rig aandelig Begavelse. Maaske de ogsaa efter hende havde deres urolige Blod, thi Faderen Hans Petersen synes at have været en stille og rolig Mand. Pastor Meylandt skriver om ham i Felsted Kirkebog (1800): "Han var en god Mand, flittig, ædruelig, havde gode Kundskaber, levede i Fred med hver Mand, gjorde ingen noget ondt, var stille, afholdt af alle, var en trofast Nabo og god Fader og Egtemand", og efter at Præsten derpaa udførligt har beskrevet hans Sygdom og Død, tilføjer han: »Han var Sognets stærkeste Mand ".

Den ældste af Hans Petersens to Sønner, theologisk Kandidat Peter Hansen Steensvang, blev kendt over hele Landet, da han 1815 i sin "Glædens Kilde" rettede et voldsomt Angreb mod de rationalistiske Præster og Samtidens Laster og Fejl. Efter et bevæget Liv fandt han Hvile paa Fremmedkirkegaarden i Konstantinopel. Om ham kan der læses i "Dansk Kirketidende" for 1847 og 1848 og i "Sdj. Aarbøger" for 1923.

Broderen Hans Hansen Steensvang fandt ogsaa først Ro, da Jorden lagde sig over hans Kiste. Midt i de trange Tider efter Statsbankerotten foretog han flere Rejser, flakkede omkring og solgte Bøger, indvikledes i Falskneri af Bankosedler, blev fængslet, brød ud, levede fredløs i 25 Aar, dels i Hjemmet og i en Hule paa Marken, dels paa Rejser og hos Slægt og Venner, meldte sig 1848 som 58-aarig Mand til Tjeneste som dansk Spion, fulgte med de danske Tropper frem og tilbage, kom atter i Fængsel - og da der blev Fred i Landet og Kongens Naade havde erklæret ham fri for al Tiltale, saa han omsider kunde passe sin Gaard som fri Mand, solgte han Fødestavnen, boede snart her, snart der, indtil Døden standsede det urolige Sind.

Da Steensvang i den efterfølgende Livsbeskrivelse ikke meddeler Aarstal, skal der her - for at lette Forstaaelsen - gives en Oversigt over hans Slægt, uddraget af Felsted Kirkebog: 
Bolsmand Peter Michelsen, Stensvang g. m. Maria Lisbeth, f. Hansen

Bolsmand Hans Petersen, Stensvang

f. 11. April 1751, død 17. Juli 1800, gift $1786 \mathrm{~m}$. Kiestin $\mathrm{f}$. Hansen,

f. 17. Marts 1765, død 25. Nov. 1851, Datter af Bolsmand Hans Hansen Jørgensen i Tombøl og Hustru Cathrine f. Jørgensen Ley fra Rinkenæs

\begin{tabular}{|c|c|c|c|}
\hline \multirow[b]{2}{*}{$\begin{array}{l}\text { theol. Kand. } \\
\text { Peter Hansen } \\
\text { Steensvang, } \\
\text { f. 8. April 1787, } \\
\text { død } 1816 \\
\text { "efter mange } \\
\text { mærkelige Hæn- } \\
\text { delser og } \\
\text { Rejser'. i Kon- } \\
\text { stantinopel. }\end{array}$} & \multirow[b]{2}{*}{$\begin{array}{l}\text { Gaardm. } \\
\text { Hans Hansen } \\
\text { Steensvang, } \\
\text { f. 15. Maj 1790, } \\
\text { død 27. Septb. } \\
\text { 1862, gift 18. } \\
\text { Febr. 1815 m. } \\
\text { Gunder Marie } \\
\text { f. Nissen, } \\
\text { f. 15. Aug. 1791, } \\
\text { død 16. Aug. } \\
\text { 1860, Datter af } \\
\text { Bolsmand Nis } \\
\text { Nissen i Tombøl. }\end{array}$} & \multirow[b]{2}{*}{$\begin{array}{l}\text { Marie Elisabeth, } \\
\text { g. m. Gaardm. } \\
\text { Nis Hansen } \\
\text { (Eriksen) i } \\
\text { Tombøl. } \\
\text { (5 Børn) }\end{array}$} & \multirow[b]{2}{*}{$\begin{array}{c}\text { Anna Cathr. } \\
\text { g. m. Gdm. } \\
\text { Peter Jessen } \\
\text { i Uge } \\
\text { (3 Børn) }\end{array}$} \\
\hline & & & \\
\hline $\begin{array}{l}\text { Peter Hansen } \\
\text { Steensvang } \\
\text { f. 1822, død } \\
\text { 23. Juni 1843 }\end{array}$ & $\begin{array}{r}\text { Stine Mar Mar } \\
\text { g. Gaardn } \\
\text { Hans Hans } \\
\text { i Stepping } \\
\text { (6 Børn) }\end{array}$ & $\begin{array}{lr}\text { ia } & \text { Anna Ma } \\
\text { nand } & \text { g. m. Gaa } \\
\text { on } & \text { Andreas J } \\
\text { e } & \text { paa Tomb } \\
& \text { (7 B }\end{array}$ & $\begin{array}{l}\text { rethe } \\
\text { lmand } \\
\text { gensen } \\
\text { Mark } \\
\text { (n) }\end{array}$ \\
\hline
\end{tabular}

Den af Steensvang forfattede Levnedsbeskrivelse foreligger ikke i Originalen. Hans Dattersøn, Gaardejer Jørgen Jørgensen (Andersen) i Tombøl (død 1922 i Bov) har afskrevet den - og fuldendt den efter Bedstefaderens mundtlige Beretninger, da de originale Optegnelser synes at standse ved Fortællingerne fra Treaarskrigens Tid. Levnedsbeskrivelsen meddeles her i afkortet Form. Den uforkortede Optegrielse ejes af Jørgen Jørgensen (Andersens) Svigersøn, Gæstgiver Peter Petersen i Bov ved Flensborg.

Cl. E.

\section{Mit Barndomshjem.}

Jeg saa Dagens Lys for forste Gang i Landsbyen Tombøl : Felsted Sogn, paa en Gaard, som kaldes 
Stensvang, henimod slutningen af det 18. Aarhundrede, og havde 3 Søskende, hvoraf en Broder var tre Aar æeldre end jeg. Vor Fader syntes, at han lige saa godt kunde give os Gaardens Navn til Dobenavn, fordi han selv blev nævnt efter samme, og indsaa, at vi vilde faa dette Navn, enten vi var dobte demed eller ej. Jeg fik altsaa i Daaben Navnet Hans Hansen Steenschwang. Min Fader, som var fodt og opilraget paa samme Gaard, hed ellers Hans Petersen, min Moder, som var en Gaardmandsdatter fra samme By, hed Kristine, fodt Hansen, og begge var de agtværdige Bonderfolk.

Min Facler var nærmest bekendt for sine overordentlige Legemskræfter, om hvilke der endnu gaar mange Fortwlinger blandt Folk, og som jeg med egne Øjne har set Prover paa. Et Par Eksempler (lerpaa vil jeg fortalle:

Han havde engang bestilt 5 Tonder Byg til Sæd paa Herregaarden Laygaart, som laa en lille halv Times Gang fra vort $\mathrm{Hjem}$. Da nu Tiden kom, at han skulde til at saa, gik han derhen for at hente dem og spurgte derfor, on han nu marte faa den Byg, han havde bestilt. Ja, det maatte han jo nok, men hvor han havde Vognen. "Jeg tænkte, jeg vilde bære den ljjem«, svarede han. Herremanden, som just var kommet til, udbrol da: "Ja, kan du det, saa vil jeg forsere dig Byggen!« Saa tog min Fader et Reb, han havde med, lagile Sækkene deri, kastede dem paa Ryggen, sagde Farvel og mange Tak og gik saa sin Vej.

Ja han var saa stærk, at han kunde trække mere end et Par Heste, som han engang viste med et Læs Tømmer, han hentede i Flensborg. Da han var kommet halvvejs op ad en Bakke, kunde hans Heste paa Grund af den daarlige Vej ikke trække Læsset videre. Som han nu holdt der, kom der en Fragtmand med tom Vogn kørende forbi ham. Han tiltalte da Manden og bad ham om at satte hans Heste for og hjælpe Lasset op paa Bakken, men Fragtmanden svarede, at dertil havde han ingen Tid. "Ja, saa maa jeg hjælpe mig selv«, sagde min Fader, hvorpaa den anden kørte videre, dog ikke længere end nedenfor Bakken, da han ventede at blive budt en klækkelig Betaling for sin Hjælp. Min Fader spændte da He- 
stene fra Vognen, greb selv fat og trak hele Læsset op paa Bakkens Top. Da han nu saa sig onı og saa Fragtmauden holde nelenfor, raabte han: "Hvad, har lu nu Tid til at se paa mig? For havde du ingen Tid til at hjælpe mig; vent, nu skal jeg hjælpe dig!« Med disse Ord rev han et Stykke Tommer ud af Lasset og truede efter liam med det. Fragtmanden gav Pisk og kørte saa hurtigt, han kunde, ind til Flensborg, hvor han fortalte, at han havde set Djavelen; han troedle nemlig ikke, at et Meneske kunde udrette det, han her havde set. - Og dog havde min Fader altid gode Heste, thi han var meget nænsom og god ved dem.

Et Par store Sten-Ledpale, som staar ved Indkørslen til Gaarden, kan enlnu den Dag i Dag bevidne hans store Styrke, thi dem bar han dertil paa sine skuldre. Mens han bar clem, brast hans Træosko itu under Fodderne paa ham, hvortil han sindigt bemærkede: "Se, kunde det Kram ikke holde det ud!«

Trods sin store Styrke blev han ikke gammel, hans Alder blev nemlig kun 49 Aar. Min Moder vedblev efter hans Dod at sidde Enke og drev Gaarden ved fremmed Tyende, hvorved den kom meget i Forfald.

Min Broder og jeg fik ellers i vor Drengealder en temmelig god skolegang, og da vi ej var tungnemme til at lare, slap vi nogenlunde for Bank. Stokken og Tampen spillede ellers i de Dage en stor Rolle ved Undervisningen; hval Hovedet ikke kunde fatte, blev Ryggen indprentet. Da det var saa almindeligt med dette Bankeri, tabtes ogsaa Frygten for samme. Det kunde saa nok hændes, at naar Læreren bankede een $i$ den ene Ende af Skolen, raabtes der i den anden Ende: "Min Ryg den klør!« og dette Raab kunde blive ved saá længe, indtil Læreren til sidst halvt afmægtig af Raseri og Anstrengelse opgav det hele og lob ud af Skolen, indtil der atter blev Ro. Men undertiden kunde det ogsaa gaa for vidt med dette Bankeri. En Pige fik engang saa meget, at hun straks maatte til Sengs, da hun kom hjem, og faa Dage efter afgik hun ved Døden.

Ellers havde min Broder og jeg i vor Drengealder mange Projekter for. Begejstrede ved Fortællingerne om vore tapre Sømænds haarde og hæder- 
lige Kamp ved København med Engelskmændene, sværmede vi især for Skibe og Søfart. Vi fik os clerfor et Fartøj bygget, som var saa stort, at det kunde rumme 6 store Drenge. Det førte baade Master og Sejl og var armeret med 6 gamle Bøsseløb som Kanoner, deriblandt $\operatorname{dog}$ een, som vi ikke turde vove at affyre, saa stor var den. Vor Sejlads gik for sig paa en stor Engstrækning, hvor der om Efteraaret blev afdæmmet for Vandet, eller ogsaa sejlede vi langs ad et større Vandløb ud til Søgaard Sø, hvor vi havde Vand nok til at sejle $i$.

Som vi nu en Dag var ved at sejle ud med vort Skib, kom der en Tiggerdreng og bad om at faa en Sejltur med os. Ja, det maatte han nok, og du skal ogsaa have den Fornøjelse at være Kanoner og affyre vore Kanoner! Drengen blev derover ellevild af Glæde. Vi sejlede saa afsted, og kort derefter kommanderede min Broder ham til at begynde med Skydningen. Med en Lunte gik han altsaa fra den ene Kanon til den anden og lo over hele Ansigtet ved hvert Knald der kom. Men da han kom til den store Kanon lagde min Broder og jeg os hurtigt ned paa Bunden af Fartøjet. Vi hørte da et forfærdeligt Skrald og et Plask og et Brøl, og da vi hurtigt kom paa Benene, fandt vi vor Kammerat liggende tudskraalende i Vandet. Vi fik ham dog hurtigt halet om Bord igen, og min Broder spurgte ham: "Hvorledes gik det dog til, at du faldt i Vandet?" "Ja", svarede han, "det gav jo saadan et Knald, som jeg aldrig før har hørt Magen til, og af bare Angst faldt jeg i Vandet«. Vi lo af Hjertensgrund, og endelig lo han ogsaa med. Noget efter spurgte min Broder ham, om han vilde affyre Kanonerne endnu engang. "Tor jeg vove det?" svarede han. "Ja, hvorfor ikke, du kan jo holde fast $i$ et Tov med den ene Haand, medens du sætter Lunten til med den anden". Ja, saa vilde han prove igen, thi denne Skydning var da en stor Fornøjelse. Min Broder ladede saa Kanonerne, den store gav han endnu stærkere Ladning end forste Gang. Affyringen begyndte saa igen, men da Drengen satte Lunten til den store Kanon, bævede han. Atter lød der et forfærdeligt Knald, og han faldt igen, men denne Gang dog i Fartøjet, siddende 
paa sin Bagdel. Glade blev vi, for nu vidste vi, at vor Kanon var sikker nok.

Der kom mange at se paa os, naar vi saaledes sejlede omkring med Danebrogsfanen paa Toppen af Masten og lystigt knaldende med vore Kanoner. Selv Præsten i Felsted,") som meget yndede Sejlads, kom for at se os sejle og fik sig ogsaa en Sejltur.

Imidlertid blev min Broder konfirmeret, og nu fik han en anden Passion. I Stedet for, som det mest tegnede til, at han skulde blive en rask Sømand, fik han nu en overvættes stor Lyst til Læsning og til at udvide sine Kundskaber. Enhver skilling, som han erhvervede sig, anvendte han til Boger og Skrivemateriale, og han tilbragte det meste af Natten med at læse og skrive. Han anskaffede sig en Lampe, som han kaldte "Sparsommelighedens Lampe«. I Stedet for Olie brændte han en Blanding af Vognbeg og Marv af Dyreben i den. Vel kunde den Lampe gore Tjeneste for Aanden og Øjnene, men Nasen derimod trakterede den med en meget modbydelig Stank. Jeg sagde ofte til ham: »Fy, for en Ulykke! hvor dog din Lampe stinker! Med den kan du jo smyge Fanden bort! Han lo ad mig og sagde: "Ja, denne gamle Krabat skal jeg nok holde borte". "Ja, det maa du vel sige«, svarede jeg, "thi det lugter jo langt værre, end naar man smyger for Hekse med Dyvelsdreck! «

Paa denne Maade hengik nogen Tid, uden at vor Moder vidste noget, men endelig opdagede hun hans Nattestudie. Det kunde hun alleles ikke lide, og derfor gjorde hun ham al den Afbræk, hun kunde, uden at det dog hjalp noget, thi da han ingen Ro kunde faa hjemme, sagte han Tilflugt i Vaabenhuset ved Felsted Kirke, og for at Lyset ikke skulde skinne ud nede ved Døren, lagde han en Sæk for. Om Dagen havde han altid Boger hos sig. Pløjelle han,

-) Pastor Nic. Meylandt, Prast i Felsted 176\%-1815, uddannet par Provst Balthasar Petersens Prasteinstitut i Tonder. Han byggede den statelige og smukke Prastegaard i Felsted og et smukt lille Enkesicie ved Vejen ned til Prastegaarden. Begge Bygninger staar endnu nasten uforandrede. 
maatte jeg ofte køre Ploven for ham, for at han kunde vinde Tid til Lasning, og saaledes gik det med hvad Arbejde han kom til.

Da vor Moder mærkede, at han ikke var til at holde fra Bogen og især efter, at hun havde set og læst meget af hans skriftlige Arbejde og talt med fornuftige Folk derom, gav hun ham endelig Tillaclelse til at følge Hjertets Drift og Ønske. Han tog derfor til en højere Skole for at forberede sig til Universitetet. Men han glemte ikke at hjemsøge vor Moders Kasse, ikke til Udsvævelse eller Ø(lselhed,") men til at anskaffe sig mange Bøger, hvilket gjorde et dybt Indtryk paa vor Moder, da hun var meget sparsommelig og paaholdende paa Mønterne. Men det blev ogsaa foleligt for os, hans søskende, især dog for mig, thi da jeg overtog hans Arveret til Gaarden, kom jeg til at tage den temmelig dyrt.

Min Broder fortsatte imidlertid med Held sin Studering, saavel ved Universitetet i Kiel som i København. Da han havde stucleret tre Aar i Kiel, gjorde han en Udenlandsrejse gennem Tyskland og Italien for at gore sig bekendt med frenmede Folks Sader og skikke. Paa denne Rejse døjede han ellers mange Genvordigheder, thi det var netop $i$ den Tid, da den store Krigshelt og Erobrer Napoleon af Frankrig bekrigede Tyskland. Saaledes var han engang naer ved at blive taget til Soldat $i$ en Stad i Tyskland. Han lagde nemlig Mærke til, at nogle Folk i Militærdragt betragtede ham meget nøje, og da han endelig havde faaet sig et Logis, bemærkede han kort derefter, at der gik Vagt paa Gaarden udenfor hans Kammer. Min Broder lod sig imidlertid ikke mærke med, at han havde nogen Mistanke, men samlede roligt sammen paa sine Sager. Da han var færdig dermed, tog han dem og traadte ud paa Gangen, hvor Vagten straks traadte i Vejen for ham, men han greb Vagten, kastede hain i Gulvet, saa det knagede, og sprang hurtigt ud af Huset og kom ogsaa lykkeligt og vel ud af Byen, hvorefter han søgte til mere rolige Egne. Efter at have oplevet og set meget, baade i Tyskland, Svejts og Italien, kom han

* Peter Hansen Steensvang afskyede I)rik og Svir, lous, Kortspil og Teater. (Se Silj. Aarb. 1923, S. 64 f.). 
Jykkelig og vel tilbage til sit Fædreland") og studerede derefter ved Universitetet i København, og efter at han heldigt havde overstaaet sin Eksamen, fik han Ansættelse som Lærer ved et stort Institut ovre paa Fyn.")

\section{Spanioler og Kosakker.}

Medens min Broder saaledes studerede og forberedte sig til aandelig Virksonihed, var jeg blevet konfirmeret og traadt over i Ungdomsalderen, mell min Virksomhed blev legemlig, thi jeg maatte straks gore Karls Gavn og Arbejde, eftersom min Broders Studeringer kostede min Moder mange Penge.

Min første Ungdonıstid var ellers en meget urolig og bevæget Tid. Paa Grund af de store Krige nede i Tyskland holdtes der stedse en Hær nede ved vor Grænse for at bevogte den, hvad der ofte medførte Indkvartering og megen Egtkørsel for os. Men værre blev det efter Aaret 1807, thi da kom Engelskmanden igen, dels vel for at hævne de Klaps, han havde faaet 1801 ved København, dels vel ogsaa for at forhindre, at vor store og gode Flaade skulde komme til at hjælpe Kejser Napoleon med hans Hær over til England. For at det ikke skulde gaa lige som sidst, havde han, den lumske Ræv, taget Lejligheden vel i Agt, thi nu kom han med en stor Flaade og Hær til Kabenhavn til en Tid, da han vidste, at vor Flaade laa aftaklet i Havnen, og Kronprinsen med hele Hæren laa ovre i det holstenske, medens en gammel, udlevet Mand, tilmed en Tysker, var Højstkommainderende i Hovedstaden. Det endte da ogsaa med, at København blev bombarderet, afbrændt og næsten odnlagt, og at den ovennævinte General udleverede Fjenden Fæstningen og vor store, kostbare Flaade. O, hvilken Sorg og Harme vakte det ikke rundt om i Landlet, da det rygtedes, at Fjenden nu sejlede bort med vor Flaade!

Da Flaaden nu saaledes var borte, blev der oprettet et slags Landstorm af baade unge og gamle

•) Om Peter II. Steensvangs Fodvandring til Italien se silj. Aarb. 1923, S. 49 ff.)

* Instituttet tilhørte Pastor Jens Paludan Müller, Fader til Digteren Fr. l'aludan Müller. 
Mænd, som skulde værne Landet og Kysterne mod Fjendens Landgang og Plyndring. Paa Højderne blev der sat Bavne, bestaaende af Tjæretønder og andre brændbare Sager, som skulde antændes for at kalde Folket sammen, naar Fjenden viste sig, og bevæbnede med Spyd eller Besser skiftedes vi til at gøre Strandvagt. Noget besværligt var det, især for os, som havde temmelig lang Vej til Stranden, men morsomme Scener forefaldt der ogsaa.

Saaledes hændte det sig engang, at en Jagt kom sejlende ind ad Aabenraa Fjord en meget maanelys Aften. En Spøgefugl af Vagten raabte da: "Saa da, der har vi den engelske Flaade!« Da Vagten ved Bavnen, som netop denne Aften havde faaet sig en bøj Snaps, hørte dette Udraab, tændte de uden videre Bavnen, som blussede lystigt op. Men hvilken Hurlumhej gav denne Spøg ikke Anledning til! Bavnene tandtes trindt omkring Fjorden. Folk ilede bevæbneds til Samlingspladserne i Landsbyerne; der hørtes Befalinger og Kommandoraab, medens Hundene tudede, og Kvinder og Børn hylede og jamrede formedelst den haarde Kamp og Strid, som nu forestod deres Mænd og Fædre. Langt om længe opdagedes det saa, at det hele var blind Alarm, - det var kun en Tørveskude, der sejlede ind til Aabenraa med en Ladning Tørv.

Ja, meget oplevede og fik vi at se i hine Dage, thi omsider sendte Kejser Napoleon en stor Hær af hans egne og af spanske Tropper herind for at hjælpe os mod vore $F$ jender, thi Sverige havde nu ogsaa sluttet sig til Englænderne.

Spaniolerne var smaa, brune, meget raske Folk, meget venlige, omgængelige og taknemmelige for, hvad man gjorde for dem. De blev imidlertid ikke liggende her paa Egnen, men trak længere nordpaa, til Jylland og Øerne, hvor de blev indkvarterede. Stort Gavn fik vi imidlertid ikke af dem, derimod afbrændte de det prægtige og stærke Slot i Kolding, som i Aarhundreder havde modstaaet Tidens og Fjendens Angreb. Der fortaltes, at det skete ved at de fyrede for stærkt i Kakkelovnen, fordi de, som havde hjemme i det varme Syden, ikke kunde udholde den netop i denne Tid herskende haarde Vinter. Men der fortaltes ogsaa, og det var vel mere 
troligt, at det skete for at indebrænde deres franske General, Bernadotte eller, som han ogsaa kaldtes, Prinsen af Ponto Corvo, thi da de kort efter skulde aflægge Ed til Napoleons Broder, som var bleven indsat til Konge i deres Land, gjorde de aabenbar Opstand. Ja, bare det var lykkedes dem at faa Bernadotte aflivet, saa havde de maaske dog udrettet noget gavnligt! thi som senere Konge af Sverige bidrog denne Mand meget til den elendige Tid, som senere kom over os, fordi eet Kongerige ikke var nok for hans Hovmod og Havesyge.

Det lykkedes Spaniolerne at faa Forbindelse med Englænderne, som tog Storstedelen af dem ombord paa deres Flaade og førte dem til deres Fædreland, hvor de fleste nok senere faldt $i$ Krigen mod de franske. Men alle kom de ikke afsted, en Del af dem blev afvæbnet og ført fangen herigennem videre sydpaa. Jeg glemmer alclrig, at en af dem kom hen til os, tog sin Chako af, og i et gebrokkent Sprog fortalte han os saa, at hans Fader, som var en rig Mand, forgæves havile budt denne Chako fuld af Pistoler (en spansk Guldmønt) for hans Liv og Frihed, hvorpaa han vendte sig fra os og blev fulustændig vanvittig. Skønt de liavde sluttet sig til vore Fjender, kunde man dog ikke andet end ynke de stakkels, ellers saa venlige Mennesker, thi Kærlighed til Fædreland og Frihed har Gud jo selv nedlagt i Mennesket.

Franskmændene beholdt vi meget længe her paa Eguen. I mit Hjem tik vi to af dem i Kvarter. Den ene, en lille Karl, hed Jean, og den anden hed Spøg. Jean var en lille, godmodig, venlig Fyr, med hvem jeg havde megen Omgang og Kommers. Spøg derimod var knarvorn, og ingen Ting var ham tilpas. Min Moder havde en L'lykke med at koge ham tilpas. Han vilde da ogsaa engang selv koge sin Mad og flk ogsaa en Del sammenmæsket. Da han var færdig med sit hogeri, smagte han, brummede, smagte igen, tog saa sin Potte og Ske, gik ud og klaskede det hele op paa en Ladeport. Efter dette Forsog blev han mere medgorlig med Hensyn til Maden. Da de drog fra os, tog Spøg Tappen af vor Øltønde, for at øllet kunde lebe bort, hvorimod Jean stak Fingeren i Hullet og raabte om $\mathrm{Hj}$ jp for at redde det.

En Franskmand beholdt vi dog for bestandig i 
vor By. Han blev nemlig skudt i en Duel og blev begravet i Bymarken Kirkebjerg, hvor de havde deres Eksercerplads.

Omsider forlod de franske dog vort Land, Napoleon kunde bruge dem andre Steder ved de evindelige Krige, som herskede i Europa. Efter hans ulykkelige Tog til Rusland, hvor næsten hans hele store Armć omkom af Hunger og Kulde i den forfærdelige russiske Vinter, om hvilken der gik gruopvækkende Fortellinger, fik vi andre fremmede, tilmed fjendtlige Folk ind $\mathrm{i}$ vort Land. Der kom Tyskere, Svenskere, Russere og Kosakker. En Trop Kosakker ankom saaledes en Dag i den haarde Vinter, som endnu af alke xldre Folk kaldes Kosakvinteren, til init Hjem, hvor de vilde lejre sig. De sngte ikke som andre Folk i Ly i Husene. Paa deres Forlangende maatte jeg tage en Gryde med Ild og følge dem. Vi gik omkring for at finde en Plads, som stod dem an. Derved kom vi ogsaa over til min Nabo, som jamırende skreg: "Gud fri os, Hans, vil du nu have dem til at afbrænde mit Hus!" Noget ærgerligt til Mode svarede jeg: „Ja, hvad skal jeg vel gøre? Jeg er jo nødt til at følge med det Troldtøj." Pladsen der passede den heller ikke, og vi vendte derfor tilbage nærmere ved mit Hjem, hvor de saa tændte et Baal. Til Brænde vilde de tage en af mine Vogne. Den fik jeg dog fra dem, og i Stedet for gav jeg dem en Del stortkløvet Bøgebrænde. En Kosak kastelle saa en Økse hen til mig med de Ord: "Bauer. arbeit!«, men med det Svar: "Nej, Kosak arbeit!", slængte jeg Gksen tilbage. Derover blev han saa rasende, at han greb sin Lanse og vilde gennembore mig. Deres Befalingsmand slog imidlertid Lansen til Side, idet han sagde nogle Ord i deres Sprog til ham. Jeg var rigtignok nær ved Døden dengang, thi jeg kunde mærke Lansespidsen mod mit Bryst, og den rev ogsaa i mine Klæder, da den blev slaaet til Side.

Kosakkerne arbejdede derpaa selv, og da Baalet var lagt til Rette og brændte lystigt, lagde de sig i en Kreds rundt om Ilden med Fodderne ind mod samme. Nogle Fødevarer, som jeg bar ud til dem, bragte os paa en mere venskabelig Fod med hverandre. Det var ellers et underligt Syn at se disse markelige Krigere ligger der, medens deres Heste 
stod i en Kreds uden om dem, med Hovedet ind til deres Herrers Hoved.

De var alle velvoksne og stærke Folk, inen der var baade ganske unge og ogsaa aldrende Mænd med langt, hvidt Skæg blandet mellem hinanden. Der var nogle af de ældre, der næppe kunde styltre afsted, naar de var paa Benene, saa stive var de, men ride kunde de, saa det havde Skik, naar de først var paa Ryggen af deres smaa, men stærke og udholdende Heste. Nogle af dem havde flere Gange i de mange Krige varet i Tyskland og kunde tale Tysk, saa man kunde gøre sig nogenlunde forstaaelig for dem.

Næste Dag foretog de en Razzia i Omegnen, som nærmest gik ud paa at skaffe Fødevarer og gode Heste; til nogen egentlig Plyndring kom det ikke. Dercfier for de afsted herfra. En sjallen god Hest fra vor By tog de nied sig, men da den ikke var vant til saalian at fare afsted som Kosakhestene, maatte de lade den staa $j$ Bov ved Flensborg, skamreden og forfangen. Derfra hentede Ejermanten den saa tilbage.

Endelig blev der dog efter saa mange Aars Uro og Forstyrrelse sluttet Fred, men det blev en skammelig og dyrekøbt Fred, som kom til at svie til os Bonder i mange Aar efter, hvad jeg senere skal komme nærmere ind paa.

\section{Karlighed og Giftermaal.}

Mens al den Uro og Forstyrrelse stod paa, havde jeg og en ung Pige fra min Fødeby fattet gensidig Karlighed til hinanden og var bleven forlovet, men næppe havde min Moder erfaret dette, førend hun og min Morbroder satte sig imod denne Forbindelse. Det var ikke, fordi min Forlovede var af for ringe Slægt, thi hendes Fader var en velhavende og meget agtværdig Gaardmand, men de havde sat sig i Hovedet, at min yngste Søster skulde have Gaarden.

(Stensvang fortæller nu meget udførligt om den sejge Kamp, som han og hans Broder i dette Spørgsmaal fører mod Moderen og Morbroderen, indtil det lykkes at faa Skifte og opnaa Moderens Samtykke til Forbindelsen.) 


\section{Trange Tider.}

Jeg blev nu Ejer af min Fødestavn, men fik ogsaa dermed til Byrde alt, hvad et Par stærke Ben kunde bære. Ikke alene fik jeg en betydelig fast. Sum at svare Renter af, tilligemed et stort Aftægt, men jeg maatte ogsaa straks udrede betydelige Penge, saavel til min Broder, da han rejste bort, som til min Søster, da hun kort Tid efter blev gift. Bygningerne, Heste og Vogne var i en højst maadelig Forfatning, hvilket voldte mig betydelige Omkostninger, saa at jeg derved fik endnu mere Gald at trækkes med. Jorderne var saa forsømte, at de først vilde have en god Pleje, inden jeg kunde gøre mig Haab om at faa noget ud af dem.

Kort derefter holdt vi saa Bryllup, hvortil der foruden vore nærmeste Paarørende kun var faa indbudte. Deriblandt var dog en af de saakaldte Brændevinsstudenter, som tilbad baade Bachus og Venus og som ved sine Drikkeviser blev til stor Modbydelighed for min Broder. - Og nu begyndte et mere alvorligt Afsnit af mit Liv.

Aaret efter mit Bryllup kom min Broder hjem fra Fyn. Han vilde nu rejse til Afrika for at forkynde Evangeliet for de vilde og uoplærte Mennesker. Han havde bestandigt under sine Studeringer ytret Lyst til at tjene Gud paa denne Maade. Nu havde denne Lyst og Længsel helt taget Overhaand hos ham. Forskellige Aarsager havde end yderligere bestyrket ham i at udføre det længe nærede Forsæt. Han havde nemlig udgivet en Bog under Titlen "Glædens Kilde",") og den vakte et stærkt Røre blandt de Lærde, især de teologiske, og skaffede ham mange Venner, men ogsaa mange Modstandere, hvorfor han ikke lod sig bevæge af sine Venners under Taarer fremforte Bønner og Forestillinger om at blive hjemme. En Del Aar derefter hørte jeg ogsaa en anden Grund. Han skulde nemlig have været gode Venner med en ung Dame af højadelig Slægt paa Fyn, men da hans Moder engang kom stampende derover, og hans Forlovedes stolte Slægt derved erfarede, at hans Moder kun var en jævn 1815.

*) P. H. Steenschwang: Glædens Kilde. Sonderborg 
Bondekone, satte de sig med Strenghed mod Forbindelsen.

Hvorom alting end er, afsted vilde han $\mathrm{nu}$. Om Morgenen meget tidligt, paa Kristi Himmelfartsdag 1816, tog han Afsked med vor Moder og sine Søskende for at gaa sit nye Kald i Møde, men i Stedet for at komme til Afrika og at udbrede Guds Rige ved at forkynde Evangeliet for de hedenske Negere, kom han til at vandre ind i Evigheden. Gud havde bestemt ham for et bedre Rige.

(Stensvang fortæller nu om, hvorledes han ledsagede Broderen paa Vejen. Undervejs havde han et Varsel, idet han saa en Mand i tyrkisk Dragt med en lang Dolk, Broderens Banemand. - Se Sdj. Aarb. 1923, S. 42 ff. Derefter udreder han Aarsagerne til de sørgelige Tider efter Statsbankerotten.)

$\mathrm{Ja}$, det var tilvisse sørgelige Tider i Danmarks Land. Gud give, at saadanne Tider aldrig oftere maa komme over vort Land og Folk!

Vi Bønder her i Omegnen besluttede nu at indgaa til Kongen med Bøn og Besværing, da han forlangte mere af os, end vi kunde yde. Efter fleres Forlangende paatog jeg mig baade at skrive Bønskriftet og at rejse til København med det, for tillige at komme til at tale mundtligt med Kongen.

Jeg gik til Flensborg for at sejle med en Skipper over til København. I Førstningen var det en kedsommelig Rejse. Da der næsten ingen Vind var, kom vi kun meget lidt fremad, men paa den tredje Dag henimod Aften fik vi mere Vind, end vi ønskede. Det blev nemlig saadan en Storm, som jeg hverken før eller senere har oplevet. Hvert Øjeblik tænkte jeg: Nu er det forbi med os! Thi jeg hørte Vandet brumme og brøle oven over mig, medens Skibet knagende og bragende tumlede fra den ene Side til den anden. Først var jeg nær ved at blive kvalt af Aske, da Vinden suste ned gennem Kabysskorstenen. Ved mit Raab blev dette afhjulpet, men derefter blev jeg gæstet af Neptuns Element, thi saa kom den ene Skylle efter den anden ned gennem Skorstenen, saa Vandet var nær ved at naa op i Køjen til mig. Jeg maatte igen brøle af fuld Hals, at de skulde stoppe Skorstenen til. At komme op, var ikke at tænke paa, da Lemmen var ganske fast tillukket. Men trods 
alt tog Skibet dog ingen anden skade, end at et Sejl blev revet bort. Det var i Sandhed en stor Naade af Gud, thi vi hørte bagefter, at mange Skibe var gaaet under i denne Orkan. Paa Landet faldt mange Huse over Ende, ja Stormen var saa heftig, at Vogne blæste om paa Landevejen.

Vi naaede endelig lykkeligt til København, hvor det gav mig megen Møje at faa Avdiens hos Kongen. Det var vist ikke lykkedes for mig, hvis jeg ikke havde haft Kendskab til Professorerne, som var min Broders gode Venner og som nu ved deres Venskab med adskillige Hofmænd skaffede mig den ønskede Avdiens. Flere Stormænd fra Jylland, som Nøden ogsaa havde fort til at soge til Kongen ligesom jeg, havde ventet derpaa $i$ over tre Uger.

Jeg kom efter 10 Dages Forlob til Kongen, og Avdiensen forlob saaledes: Jeg kom ind og gjorde Irig saa krum som en Bue. I det samme kom Kongen, som stod noget tilbage i Salen, farende lige hen til mig, standsede brat, gjorde derpaa et Trin tilbage, støttede sig paa sin Sabel og spurgte i en barsk Tone: "Hvad vil han?" Jeg samlede nig sammen, rettede mig op og sagde ham kort og godt, at efter de ulykkelige Tidsomstændigheder kunde vi Bønder aldeles ikke bestaa, men havde den bitreste Armod i Vente, hvis vi ikke kunde faa Skaansel og Lettelse i de svære Skatter. Dertil svarede han: "Der skal nok ske noget til det almindelige Bedste«, og han vilde vende sig fra mig. Men i det samme traadte jeg frem og overrakte ham mit skrevne Bunskrift. "Hvad vil det sige?" spurgte han. "Det er netop det sanıme, som jeg i Korthed har sagt mundtligt", svarede jeg. "Jeg takker!« sagde han, og dermed var Avdiensen til Ende. Det var dog gaaet mig bedre, end det gik en stakkels Skolelærer af mit Bekendtskab, som, da Kongen ved en vis Lejlighed standsede brat foran ham og saa ham ind $i$ Ansigtet, udstødte et langtrukket "Øh!« og segnede bagover, saa han satte sig paa Bagen, hvorover Kongen smilede og gik videre. Efter flere Dages Rejse over Sjælland og Fyn kom jeg uden videre Hændelse hjem igen. Fjorten Dage derefter ankom min Indstilling fra Kongen til de over os fungerende Øvrighedspersoner, hvilke fandt sig forurettede eller rettere sagt trufne ved 
vort Skrift, thi jeg havile rort en Smule ved Sandhedstrommen. Der forlob nogle Uger, inden vi kunde faa vore Klager stadfæstede af de Herrer. Hvad der saa skete til det almindelige Bedste, efter Kongens givne Ord, var dette: Han laante Penge, for at enhver efter sin Ejendoms Beskaffenhed kunde faa Laan, men skatterestancer skulde betales teruninsvis. Det var derfor i nine Tanker et Plaster, som kunde læge og trække paa een Gang. Byrilen blev den samme, men den fysiske Kraft mindre og minlre, saa at den aldeles forsvandt for mange.

Jeg sank ogsaa dybere og dybere i Grold. Skat og Renter var der ikke at tænke paa at faa betalt, saa at jeg tik betydelige Restancer. Til dette Onde slog der sig saa et andet, idet jeg faldt i en meget haard sygdom, som bragte mig paa Gravens Rand ng tog betydelige Penge, da jeg maatte bruge baade Doktor og Apotek. Jeg var saa syg og svag, at ingen troede, at jeg kunde leve, og jeg skulde ligge og hore paa, at min stakkels sorgende Kone tik Paamindelse om at holde mine Ligklæder til Rerle. Under min sygdom fik jeg Besog af mange, som kom for at se til mig. En af mine Kreditorer becerede mig ogsaa nied et Besng, men da jeg saa et stort Papir stikke op af hans Lomme, blev jeg saa syg, at jeg ikke kendte et Menneske, hvorfor han forlod mig, meget beklagende, at han ikke var kommet for, saa han kunde have faaet Obligationen indfort i Protokollen.

Da jeg var konmet nogenlunde til Sundhed og Kræfter, tog jeg atter fat paa mit Arbejde, hvorved jeg baade fik Appetit og god Søvn, men en Nat sov jeg dog for haardt, thi en Tyv havde benyttet sig af min trygge Søvn til at bryde ind gennem et Vindue. Han tog med sine lange Fingre vort Sølvtøj, der havde en Værdi af omtrent 80 Daler dansk Rigsmønt. Jeg blev meget vred og onskede Tyven ad Helvede til, men min Kone græd og klagede: "Hvad skal vi nu en anden Dag, naar vi skal have Barselgilde, og alle vore Sølvskeer er borte!" "Ligemeget med det! sagde jeg, "hvem der ikke kan spise med Træske, kan lade Maden urørt. - Men nu maa jeg efter den forbandede Tyv, som sikkert er den lumske skomager fra T..... 
han boede. Her erfarede jeg, at han til samme Tid, som han havde besøgt os, havde begivet sig til Tønder, hvor der just var Marked i disse Dage. Jeg begav mig straks paa Vej dertil, men med det Forspring, han havde, havde han naaet Tønder forinden og havde faaet vort Sølvtøj solgt til en Jøde, som var en af Tyvens Haandlangere. Jeg meldte Sagen til Øvrigheden - vi hørte dengang endnu under Tønder Amt - og fortalte tillige, at jeg havde truffet en god Ven paa Markedet, som havde fortalt mig, at han havde drukket med Skomageren, og at han havde undret sig meget over de mange store Pengestykker, som denne kastede omkring sig med. "Se at faa Deres Ven til at drikke videre med ham «, sagde de, "Knægten vil jo snart være døddrukken, og det vil da være let for Deres Ven at undersøge, om han har noget Sølvtøj hos sig, og muligt kan hans Ord ogsaa forraade ham."

Min Ven paatog sig den omtalte Kommission og gjorde sig ogsaa al tænkelig Umage, men til ingen Nytte. Tyven slap saaledes, og vi mistede for bestandigt vort Sølvtøj.

Kort derefter velsignede Gud os med en lille Datter, og ved Barselgildet blev jeg overbevist om, at Træskeerne godt lod sig bruge, thi Gæsterne langede rask og villigt nok til Fadet.

\section{En Rejse til Kobenhavn.}

Kort derefter fik jeg Brev fra en meget høj Herre, som meget høfligt bad mig give ham al mulig Underretning om min Broder og tillige laane ham min Broders Breve til Gennemsyn. Skønt det kostede mig baade Tid og nogle Skillinger, opfyldte jeg hans Forlangende og fik ogsaa om en føje Tid Brevene tilbage med en venlig Skrivelse, hvori han bevidnede mig sin dybeste Taknemmelighed.

Glæden ved at modtage Breve fra min Broder fik imidlertid en brat Afslutning, thi der var næppe gaaet et Aar hen, før jeg fik at læse i »Hamburger Børsenhalle«, at min Broder i Tyrkiet var blevet overfalden af Røvere og ved den østerrigske Konsuls Hjælp haardt saaret og syg var ankommet til Konstantinopel, hvor han var død og bleven begravet paa 
den Kirkegaard, som tilhører de europæiske Kristne, og som Følge deraf var alle hans Papirer af den danske Konsul sendt til København. I den saa uventet tilstødte Sorg skrev jeg til en Ven i København og bad ham undersøge, hvad Rapport der var ankommen til det udenlandske Departement og bad ham tillige at faa ethvert af min Broder skrevet Dokument udleveret. Noget derefter fik jeg Brev fra min Ven, og med samme fulgte en lille fransk Rapport fra Kongens Afsending i Konstantinopel. Flere Papirer fik jeg ikke, jeg havde haabet, at hans Dagbog ogsaa havde været med.

I Følge flere Beretninger i udenlandske Blade, som gav mig Haab saavel om, at min Broder kunde være i Live som at der dog gaves Papirer efter ham, hvori han beskrev sin Rejse, og hvoraf især hans Dagbog kunde være mig til megen Gavn, paatog jeg mig en Rejse til København. Jeg sejlede med en Skipper fra Flensborg, og efter nogle Dages heldig Sejlads ankom jeg til mit Bestemmelsessted, hvor jeg straks med længselsfuldt Sind begav mig til det udenlandske Departement. Men jeg fik ikke flere Papirer eller flere Oplysninger, end der var mig tilstillet. Efter at have besøgt min Broders og nine Venner, gjorde jeg mig fardig til Hjemrejsen og besluttede at gaa Søvejen igen, hvorfor en Ven forærede mig en Flaske god, gammel Vin, som skulde være god imod Søsygen, naar jeg undertiden tog en Slurk af den.

Jeg kom atter med et Flensborger Skib. Men dette var saa tillastet saavel med Ladning som Passagerer, hvoraf en Del af saakaldte fornemme Folk havde taget Kahytten saa fuldstændigt i Besiddelse, at vi andre, jævne Folk maatte søge vor Tilflugt til Lasten, som bestod af Arter og Hvidkaal. Her laa vi om Natten som i et Fængsel, thi Lemmen blev hver Aften fast tillukket, saa at det oven i Købet var saa mørkt som i en Grav, men ingenlunde saa stille som i en Grav.

Vi sejlede fra København i stærk Modvind, hvorfor Skipperen den første Dag satte Kursen over til den skaanske Kyst og til Aften lagde sig for Anker der. Da jeg saa, at de satte en Jolle ud for at gaa i Land, fik jeg Lyst til at gøre dem Følgeskab for at sætte min Fod paa svensk Bund. Vi sejlede altsaa af 
og kom i Land og gik et lille Stykke op fra Stranden til en temmelig stor, træbygget Gaard, hvor vi gik ind, thi skipperen havde til Hensigt at købe Fiøde. Vi kom ind i en meget stor Stue med et flere Alen langt Ilisted, hvor der brændte en stor Ild af lange Fyrresplinter. Foran denne sad en stor Del af Husets Folk for at varme sig. Vor Hilsen gengreldte de med de Ord: "I Vorherre Jesu Navn vare velkommen!« Da jeg hørte dette, gav det mig Tanker, thi jeg syntes, at det var smukt, om den Hilsen blev brugt i ethvert kristent Hus. Da jeg var alt for nysgerrig efter at se alting noje efter, fattede Folkene Mistanke til mig, og jeg blev overbevist on, at de ansaa mig for en Tyv, thi et stort gammeldags Lommeur, som hang paa en stolpe, blev hastigt taget ned og stukket i en Lomme. Jeg kunde næppe bare mig for at le. Da jeg dog nodig vilde have, at Folkene skulde beholde den Tro om mig, fortalte jeg dem, at jeg saa Hus og Bohave saa noje efter, fordi det var forste Gang, jeg var i et svensk Hus. Endvidere fortalte jeg dem, at jeg havde en Gaard i det Slesvigske og beskrev dem nogenlunde, hvorledes denne var beskaffen, og hvad for Saelarter vi dyrkede. Da de hørte (lette, blev jeg betragtet med mere milde Øjne, og det blev meget venskabeligt mellem os. Skipperen havde imidlertid faaet et Par Flasker fyldt med Flode og gjorde sig rede til at gaa. Vi sagde dem derfor Farvel, hvortil de onskede os "Med Gud en lykkelig Rejse!«

Ved Nattens Frembrud kom vi ombord paa Skibet igen, og jeg søgte straks min Plads i Lasten og lagde mig i de kære Erter ligesom de andre. Men at komme til at sove, var der ikke at tænke paa. Her var en Mulder og Bulder som i en Jødeskole, og saaledes som der blev kastet med de Erter, og de slog baade snært og haardt! At forlange Ro vilde have gjort ondt værre, her var ikke andet at gore end at væbne sig med Taalmodighed. Jeg trak derfor mit Slag op over Hovedet for at have mine Øjne i Fred for Erterne og laa saa roligt og hørte til. Øjnene kunde jeg paa denne Maade nok beskytte, men Næsen derimod ikke, da Luften blev saaledes beskaffen, at jeg tror, hvis en Hue var bleven kastet $i$ Vejret, saa vilde den være bleven svævende over os som en Komet. 
Omsider kunde jeg forstaa, at der var en Katolik iblandt os, thi hver Gang der lød en fæl Ed eller Band, mumlede han "Ave Maria!" og paakaldte hende.

Saaledes forløb det meste af Natten, og Søvn fik vi ikke meget af. Endelig blev Lemmen taget af, og vi var ikke sene til at komme op i frisk Luft. Jeg var tillige meget begærlig efter at faa mit Rejseselskab taget bedre i Øjesyn. Der var en, som der om Natten havde været meget Spektakel med, og som ofte blev raabt med Navnet "Sorte Mads«. Ham fik jeg nu Øje paa. Det var en lille bredskuldret Karl med en Mave, der stod frem som en lille Bakke, et Bevis paa, at han i sin Tid havde spist og drukket meget. Derefter spejdede jeg efter ham, som flittigt havde læst "Ave Maria« og fandt ham ogsaa snart. Jeg antog ham først for en tysk Haandværkssvend, men ved hans fine Underkjole, som tilmed havde et eget Snit, blev jeg snart overbevist om, at han ikke alene var en Katolik, men en Pater eller Jesuit. Desuden fik jeg opdaget, at han var fra Sydtyskland.

Endelig lettede vi Anker, hejsede Sejl og sejlede videre, men med lige kontrærig Vind som i Gaar. Skipperen satte sin Kurs stik Sydøst. Det varede ikke saa længe, før vi kunde se Land, hvorfor jeg spurgte Skipperen, hvad dette var for et Land. "Det er Bornholm «, svarede han. "Herre Gud!!« sagde jeg, »det er jo en gal Vej til Flensborg!« "Ja«, sagde han, "det bliver desværre ikke derved endnu." Deraf kunde jeg forstaa, at vi vilde komme til at krydse længe i Østersøen og kom til at tænke paa min Madpose, som kun var forsynet for to Gange 24 Timer.

Da det atter blev Aften, maatte vi igen søge vort Logi i Lastrummet, og da jeg ikke følte mig saa ganske vel tilpas, tog jeg min Flaske Vin med. Jeg maa imidlertid ikke have været forsigtig nok, da jeg satte min Flaske i Arterne, thi da jeg efter at have sovet i nogen Tid tog til min Flaske for at faa en Slurk af den, fandt jeg, at den var mestendels tømt. "Det skal den Slikmund faa betalt!« tænkte jeg, satte Flasken for Munden og tømte den, hvorpaa jeg fyldte den med noget Vand, som man ellers ikke plejer at opbevare i Flasker til Drikkevarer. Saa satte jeg Flasken hen paa sin Plads og. lod, som om jeg var falden i Søvn. 
Det varede heller ikke saa ret længe, for der atter var Fingre ved Flasken. Jeg hørte, hvor Proppen losnedes, og at een tog et Par forsvarlige Slurk, men saa satte han Flasken og begyndte at spytte og spytte, og omsider begyndte han at kaste op. Styrmanden, som havde sit Lukaf ved Siden af os, begyndte at bande og gale, hvad det var for Svineri i Erterne. Ja, det blev rigtignok nogle dejlige Spisearter!

Da vi næste Morgen kom op paa Dækket, var vi alle meget nysgerrige efter at faa at vide, hvor vidt vi var komne. Jeg spurgte derfor Skipperen, hvor vi nu befandt os paa Søen. "Det maa Gud vide«, svarede han mig. Nu, trenkte jeg, saa maa jeg vel henvende mig til ham, det er da altid en god Trøst, at han er Overstyrmand. Vi saa os omkring til alle Sider, om vi ikke kunde øjne Land, men der var ikke andet at se end Himmel og Hav. Om Natten blev det blikstille, og om Morgenen fik vi en tyk Taage, hvorfor vi, drevne af Strømmen, løb paa Grund paa Falsters Kyst. Nu var det en Lykke for os, at det var saa stille, mell alligevel blev vi, og især Skipperen, ikke saa lidt bange. Der blev straks gjort Anstalter for at faa Skibet flot, hvilket lykkedes os ved at et Anker blev lagt $i$ en Baad og roet saa langt ud fra Skibet, som Ankertovet vilue række, og der kastet i Havet, hvorefter vi alle tog fat paa Spilstokkene, saa at det knagede og bragede i Skibet, som endelig derved haledes om paa Siden og atter blev flot og igen kom til at sejle.

Men Vind og Vejr blev ved at spille Gæk med os, saa at vi forst ved Aftentid kom krydsende ind til Langeland, hvor der blev kastet Anker. Her maatte en Del af os gaa i Land for at kobe Levnedsmidler. Næste Dag maatte vi krydse og lavére os frem lige til Aften. Da Solen var gaaet ned, drejede Vinden sig mere til Gunst for os, saa at vi denne Nat skar hurtigt gennem Søen, hvilket viste sig den følgende Morgen. Thi da saa vi i nogen Frastand ikke blot mange Skibe, men ogsaa en Kobstad, med flere Kirketaarne knejsende i Vejret. Vi spurgte alle, hvad dette dog var for en Stad. Skipperen var lige saa ukyndig som vi andre. Endelig kom der en Jagt, og vi raabte over til den: "Hvorfra kommer De?" "Fra Trave- 
münde«, lod Svaret. Vi forstod altsaa, at det var Lybeck, som laa foran os. Skipperen tog derpaa Kursen tilbage, og da det kom nær til Aften, sagde han: "Da vi nu sejler for saa gunstig en Vind, kan vi let naa til Als Bugt, og der vil vi kaste Anker for ikke at sejle gennem det smalle Farvand ved Nattetid til Flensborg."

Vi kom altsaa om Natten til at ligge for Anker $\mathbf{i}$ den Formening, at vi laa under Als, men da det blev Dag, blev vi alle meget ilde til Mode ved at opdage, at vi laa i en Havn ved Langeland, og tilmed var Vinden nu sprungen saaledes om, at vi atter maatte krydse os frem, saa at let, kort at fortælle, tog 10 Dage og 10 Nætter, inden vi naaede Holnæs, hvor jeg med Glæde lod $\mathrm{mig}$ scette i Land. . Jeg havde da faaet nok af den Sejlads. Jeg tror, at Moses har ikke krydset værre $\mathrm{i}$ den arabiske Ørken med Israels Børn, end denne Skipper krydsede med os i Østersøen.

Da jeg forst var kommet i Land, tog det kun nogle Timer for mig at naa til mit Hjem. Her havde jeg den Glæde at finde min Kone og mine Born i god sundhed.

\section{De falske Rigsbanksedler.}

En Maaneds Tid efter min Hjemkomst skænkede Gud os den Glæde, at min Kone fodte en Søn, som i Daaben blev opnævint efter min nu clesværre afdøde Broder. Straks derefter kom der en mageløs Strøm af Breve til mig, men det var rigtignok ikke Gratulationer i Anledning af min Kones lykkelige Nedkomst, det var Kravebreve, Mandater og Befalinger i Forening med flere Hundrede Dalers Opsigelse. Derved blev vi sat i en næsten fortvivlet Stilling, da det jo var umuligt at skaffe saa mange Penge i disse ulykkelige Tider og Forhold. Hvad der mest skar mig i Hjertet var, at min Kone $i$ hendes svage Tilstand skulde ligge og sukke og klage over al den Genvordighed nxsten hele Natten. Jeg søgte at trøste hende, men det var forgeves. Hun fik da ogsaa en slem Feber, hvorved Barnet ogsaa blev sygt.

Jeg maatte gøre mange Rejser over de modbydelige Mandater og hist og her aflægge Besøg hos de gode Pengemænd, men det var alt til ingen Nytte. 
En Slægtning af mig, som efter eget Ønske var blevet Sognefoged, havde den Are og vistnok ogsaa Fornøjelse at overbringe mig de afskyelige Mandater. Hver Gang, han kom med dem, malede han alt saa sort som muligt for mig og sagde, at jeg nu snart vilde komme til at gaa fallit. Denne Mand kunde med Lethed have hjulpet mig og maaske derved have sparet mig for den Ulykke, jeg senere kom i.

Da jeg mærkede, at det blev mig umuligt at faa Penge til Laans, besluttede jeg at sælge af min rorlige Ejendom. Men der var den ulykkelige Rigsbankskat atter $i$ Vejen, thi næsten enhver Bonde var $i$ den samme Knibe som jeg. Da jeg solgte mange af de nødvendige Redskaber for at skaffe Penge, blev min Bedrift sat meget tilbage, og min Kredit var borte.

Endelig blev jeg tilskyndet af nogle af mine Venner til at udgive $i$ Tryk de Breve, som jeg havde faaet fra min Broder paa hans Rejse i Afrika, hvorved jeg jkke alene kunde tilfredsstille hans Venners Langsel efter at erfare noget om ham, men ogsaa selv have en Fordel. Brevene blev altsaa trykte) og i Pakker sendt til de forskellige Boghandlere, og jeg havde den Glade, at de vandt almindeligt Bifald.

Efter: Bogtrykkerens Ønske beholdt jeg en betydelig Del Eksemplarer, som jeg skulde se at faa solgt paa Fyn, hvor min Broders Navn var godt kendt. Denne Rejse til Fyn blev en ulykkelig Rejse for mig. Thi derved traf jeg sammen med een, som forte mig i noget, jeg aldrig havile tænkt paa eller troet, at jeg i mine Levedage skulde konmme i Lag med. Og det forte til mange Genvorligheder, nıegen Sorg og Kummer for mig og ister for min Familie og havde til Følge, at jeg i 25 Aar maatte føre et fredlost Liv. Dette gik saaledes til:

Paa min Omrejse i Landet maatte jeg ofte sporge efter Vej for ikke at gaa for langt ud af min Tur. Saaledes traf jeg en Dag en Mand, som jeg ogsaa spurgte mig til Rette hos. Saa kunde vi folges ad, sagde han, for han skulde samme Vej. Vi talte om et og andet, og derved faldt Talen ogsaa paa den ulykkebringende Rigsbankskat. "Jeg er«, sagde jeg,

*) II. H. Steenschwang: Hreve fra Theologen P. H. steenschwang ран hans udenlandske Rejse. Itaderslev $18: 2 \cdot 2$. 
sen Gaardmand ovre fra det Slesvigske, som ved denne forbandede Rigsbankskat og ved de urimelige lave Priser paa Landmandens Produkter er kommet saaledes i Klemme, at jeg nu maa tærske omkring med disse smaa Bøger for at tjene lidt Penge til $\mathrm{Hjælp} \mathrm{og}$ Stotte." Hertil gav Manden et dybt Suk og sagde: "Jeg har en Broder, som er bleven ganske ulykkelig ved tenne Rigsbank. Jeg vil nu i Korthed fortælle Dem hans Skæbne: Han og jeg vidste ikke andet, end at vi var i Besiddelse af Formue, men hvad vi ejede i Hundreder af Rigsdalere, det blev til faa Daler eller Skilling, fordi Rigsdalersedlerne, enten de var store eller smaa, ikke mere svarede til deres Paalydende. Hvor de efter Præg og Paategning skulde gælde for 50 eller 1 Daler, gjaldt de nu ikke mere end 1 Skilling Lybsk for hver Daler, hvilket foraarsagede os et stort Tab og allermest for min Broder, som drev en Handelsforretning. Som ved et Tordenslag blev denne knust paa en Gang, og han maatte standse paa Grund af Mangel paa Kapital. Enhver som skyldte ham noget, kom nemlig og smed ham de værdiløse Lapper, som han maatte tage til fuld Værdi efter deres Paategning, og som i det samme blev indløst af Regeringen for ganske ubetydeligt, og i Stedet for kom nu den saakaldte nye Rigsbank. Min Broder, som saa sig stedt i Armod ved slige Sedler, som ikke svarede til deres foregivne Værd, handlede efter Tyskernes Ord: "Not macht Rat«. Det faldt ham nemlig ind at faa sit Tab indhalet, og til den Ende vovede hall sig til at efterlave de nye Rigsbanksedler, hvilket ogsaa lykkedes saa skuffende, at de ej var at kende fra de af Banken udstedte Sedler. Men som det almindeligt gaar i Verden, at enhver Ting, den være god eller ond, har sin Tid at grassere i, saaledes gik det ogsaa med dette. Lige saa uforskyldt min Broder var blevet fattig, lige saa selvforskylit blev han nu langt mere ulykkelig. Kort sagt, det blev opdaget, at der var flere, som havde grebet til dette Middel, baade i Kobenhavn og Jylland, de blev alle fængslede og forte til Odense, hvortil min Broder ogsaa blev fort, og hvor han sad fangen i temmelig lang Tid. Men omsider fandt han Lejlighed til at undvige, og nu maa han, hvis han lever, svæve i det fremmede."

Alt imens var vi komne til Mandens Gaard, og 
han havde budt mig med indenfor. Jeg var blevet bitter i Sind, ikke paa den ulykkelige Broder, men paa dem, der lader saadanne Aarsager opstaa, saa mange tvinges paa Afveje og bliver stødt ud i Jammer og Elendighed. Jeg gav Udtryk for disse Tanker og sagde, hvis det skulde ske, at den ulykkelige Broder paa sin Flugt kom til mit Hus, vilde jeg slet ikke betænke mig paa at optage ham, og jeg vilde heller ikke have gjort mig Samvittighedsskrupler ved at gøre Brug af hans Pengesedler, thi saaledes som Kongen nu gaar frem mod Bondestanden, kan jo næsten ingen bestaa.

Endelig var vor Samtale til Ende, og jeg rejste mig for at gaa videre. Jeg agtede at naa $B . . .$. samme Dag. Han viste mig Vejen og bad mig om at besøge ham paa Tilbagevejen, hvilket jeg dog ikke vilde love, da jeg ilede efter at komme hjem. Næste Dag kom jeg nok i Nærheden af hans Hjem, men jeg tog mig ikke Tid til at besøge ham. Jeg ilede til Odense og gjorde mig der fuldstændig færdig til Hjemrejsen.

Anden Dags Morgen, som jeg netop vilde afsted, traf jeg Manden og hans Kone paa Gaden. De sagde straks: "Det glæder os meget, at vi traf Dem. Vel havde vi et lille Erincle her i Byen, men det var dog mest for at træffe Dem, at vi er komne hertil. Om vi ellers tør være saa fri, saa har vi en Bøn til Dem, og det er, om De ikke vil besøge os igen, enten i Dag eller i Morgen. Vi har en god Bekendt, som ønsker at komme over $i$ det slesvigske for at soge Employ, han har slet intet Bekendtskab derovre, og det er derfor vor Bøn, om De vil tage ham med og være ham behjælpelig.« Jeg undskyldte mig, at jeg ikke kunde komme i Besøg hos dem, da jeg hurtigst vilde hjem, og tilbød at give dem min Adresse, saa kunde Manden let finde mig, og jeg skulde saa gerne hjælpe ham. Men de sagde, at jeg gik ikke ud af Vejen, hvis jeg gik med dem, og at jeg gjorde dem en stor Tjeneste, hvis jeg selv vilde træffe Aftalen med deres Ven.

Saa drog jeg med dem for i en Fart at gøre Aftale med den fremmede. Jeg ventede en Time $i$ deres Hjem, men da han stadig ikke kom, vilde jeg give dem min fuldstændige Adresse og derefter gaa videre. 
De blev dog ved at holde paa mig, og da det var blevet nær til Aften, tog jeg imod deres Tilbud om at blive der Natten over. Det var meget sildig Aften, da der bankedes paa Døren, og ind traadte en velklædt, temmelig ung Mand, som med Anstand og Høflighed bød os "God Aften!" Med Tak og Genhilsen blev han bedt at tage Sæde hos os, hvorefter der blev en kort Pavse, og siden taltes der kun om Vind og Vejr og slige ligegyldige Ting. Omsider fandt jeg Lejlighed til at spørge Manden: "Er det ham, som vil med mig over til Slesvig? " Ja", svarede han, wham er det«. Jeg spurgte saa den fremmede: "De er vel den Person, som vil rejse med mig til Slesvig?" "Ja«, svarede han, "det er mig, men der er netop indtruffen Forhindring, saa jeg ikke kan rejse de første otte Dage«. Han nævnte derpaa sit Navn, som var N. Møller, og fortalte, at han vilde rejse videre ud $i$ Verden. "Kan man maaske faa Guldpenge ovre hos Dem? Jeg ved, at den Slags Penge skal man gerne have, naar man skal rejse i fremmede Lande«. Det vilde der ikke være noget i Vejen for, mente jeg, thi da min Broder rejste bort, fik han sine Sølvpenge byttet med Guldpenge. Hos de store Købmænd i Flensborg fandtes der sædvanlig Guld nok.

Han bad mig saa om at veksle 100 Rigsdaler i Guld. Jeg vilde give ham Kvittering for Pengene, men det vilde han ikke engang have. 100 Rigsbankdaler i Tidalersedler laa allerede paa Bordet, og jeg begyndte at pakke sammen paa dem, da han satte mig i Forundring ved at sige: "Holdt! der er noget ved dem!" Jeg sagde: "Ja, der er ikke blot noget, men der er meget ved dem, og jeg forstaar saa godt, at De betænker Dem ver at lade mig løbe af med Deres Penge." "De forstaar mig ikke«, siger han, »kan De ikke nok se noget paa de Sedler, som ligger foran Dem? " "Nej, ikke anclet, end at de ser noget gammelt og brugt ud". - »Ja, men er der ellers ikke noget ved dem? «. Jeg tog dem saa skarpt i $\varnothing j e$, men kunde ikke finde noget, hvorfor han da ogsaa blev nodsaget til selv at trække Ræven ud af Hulen og vise mig, at Stemplet manglede.

"Vil De nu gore Brug af Sedlerne", sagde han, "saa vil jeg sætte Stemplet paa dem, og jeg forsikrer 
Dem, at ingen skal kassere Sedlerne, thi Kopien er fuldstændigt Originalen lig, og jeg vil give Dem halv Rabat til Fortjeneste«. Ved at høre dette, var det, ligesom jeg tabte mig selv. Han saa paa mig, og jeg saa paa ham. Omsider siger han: "De er vel bange for at have noget at bestille med dette? « "Nej, saamænd er jeg ej«, sagde jeg, »og jeg tror ikke, at det nogensinde skal anfægte mig, thi det forekommer mig, som om jeg ser Kongen med en Pisk i Haanden, og denne Pisk har som Navn Rigsbank, med hvilken han nu slaar haardt, og derfor er man nødt til at springe over Lovens Plankeværk «. - "Men lige saa haardt som han nu tvinger mig til at springe over Lovens Plankeværk, som De siger, lige saa haardt vil han ogsaa straffe». - Jeg tog en Seddel og sagde: "Jeg vil dog se efter, om Kniplen ikke staar ved Vedkassen, ligesom ved de saakaldte 2 Speciessedler «, som var en sand Originallogn og Falsk, da de skrev dem for 2 Species, medens de kun gjaldt for 2 Skilling. Men her paa disse Sedler fandtes der ikke et Ord om, at det var forbudt at eftergøre samme, saaledes som paa de omtalte Speciessedler. Jeg fortalte mine nye Venner det og sagde: "Vel ved jeg, at Loven dommer den haardt, som slaar falske Penge, men det er jo ogsaa noget andet, thi Penge er en Mont af Metal og ikke af Papir. Der kan ikke tænkes nogen synderlig Straf, fordi disse Papirspenge udgives eller efterlaves, thi de, som begik det store Falskneri ved Speciessedlerne, undgik baade Tiltale og Straf."

"Jeg vil nok gaa i Kompagni med Dem", sagde jeg saa, "men dog ikke længere, end til jeg har faaet mine Skatterestancer betalt og andre Ting $i$ Orden, som er komne af Lave ved denne Rigsbankskat. For det andet maa De fuldt og.fast love mig, hvis De efterdags forfærdiger flere Sedler, end jeg tager Del i, at De aldrig vil nævne mig, hvis det skulde briste i Stykker. For det tredje ønsker jeg at vide, om De staar i Forbindelse med flere, for saa er det højst betænkeligt at binde sig dertil«: Han svarede: "Jeg har ogsaa fast besluttet, at jeg ikke vil vedblive længere, end til jeg har min Skade nogenlunde generstattet. Jeg kan ogsaa forsikre Dem, at der fra min Side ikke skal blive flere indviet 
eller gjort delagtige i vort Foretagende«. — "Saa er vi færdige medl vor Overenskomst«, sagde jeg, "lad os nu gøre Haandslag paa, at ingen af os vil vedblive længere dermed, end vi nu har aftalt!« — "Her er min Haand!« — Og her er ogsaa min!« — Pagten var altsaa afsluttet.

Vi forføjede os derpaa til Sengs, og jeg sov roligt til naste Morgen. Jeg fik da de hundrede Rigsdaler i de Sedler, som jeg havde betragtet saa nøje, og som nu var stemplecle. Desuden tik jeg en Adresse, under hvilken jeg skulde skrive til ham, da han nok onskede at erfare, hvorledes det gik mig med disse Sedler. Efter at.have spist Frokost, tog jeg Afsked med mine nye Venmer og begav mig atter paa Hjemvejen. Nu var altsaa det første skridt gjort, som førte mig og mange til Anger, Kummer og Kval. Da jeg var gaaet et Stykke hen ad Vejen, tog jeg Sedlerne frem og betragtede dem meget nøje. Man skulde ikke tro eller tænke, at de var skrevne med en Pen, saa nøjagtigt var le ægte Sedler lige, selv Papiret var aldeles lig de ægte. Jeg fik senere at vide, at de ogsaa selv havde forfærdiget Papiret. Hos en Smed et Steds derovre paa Fyn blev Materialet slebet eller malet, og saa forstod de selv at lave Papiret.

Alt som jeg gik hen ad Vejen, gik der mange Tanker gennem mit Hoved. Det var, som om en Stemme talte til mig og sagde: "Du er kommet paa en urigtig Bane, som vil kunne føre dig i en bundløs Afgrund «. Min Gang standsede af og til, og jeg tærnkte frem og tilbage. Paa den ene side var der Fare, og paa den anden truede Pengeknibe, men jeg tærnkte: "Nu maa du gaa frem, som du har begyndt, har du først sagt A, maa du ogsaa sige B«. Desuden villste jeg, at den fordrukne Herremand, som var bleven vor Skatteoppeborselsembedsmand, nok skulde gore mig Helvede saa hedt som muligt, da han for visse Aarsagers skyld tragtede efter at faa fat paa min Gaard.

Jeg gik altsaa videre paa den Bane, som jeg havde begyndt at betræle, men ikke uden at Stemmen $i$ mit Indre vedblev at foreholde mig, at jeg var faren vild. Jeg vendte nu mine Tanker til Himmelen og bad til den barmhjertige Gud, at han i Naade 
vilde tilgive mig, hvis jeg forbrød mig paa hans Lov, da det dog ikke skete af Begærlighed efter Rigdom, men af Trang og Trang. Jeg blev derved noget beroliget.

De Sedler, som jeg havde faaet, gik rask fra Haanden uden at vække den mindste Mistanke. Efter Løfte skrev jeg derfor til Møller og lod ham vide, at det var gaaet efter Ønske. Da en kort Tid var forløben, kom hall over i Besgg hos mig og overgav mig en lignende Sum i Sedler og modtog sin Andel i de allerede omsatte Penge. De nu modtagne Penge kom ligeledes hurtigt og ubemærket ud blandt Folk. Jeg gav ham Meddelelse, og han kom hurtigt igen og overlod mig en Sum i samme Slags Penge, som ogsaa gik glat fra Haanden. Da jeg nu saaledles var kommen til Penge, var jeg ikke sen til at soge Skatteopkræveren for at faa afbetalt af mine Hestancer.

Efter at det nu var gaaet godt for os flere Gange, blev vor Aftale, at der ikke maatte optages flere Deltagere i vort Forehavende, brudt, thi der kom flere med. Endelig kom Moller igen, og det blev for sillste Gang. Nu medbragte han en storre slags Seller, nemlig Halvtredsindstyvedalersedler. Han drog nu selv med til Flensborg, hvor han straks blev genkendt af en eller anden, som det senere hortes. Tilmed gjorde han mig det ikke alene vanskeligt, men ogsaa farligt, da jeg snart maatte veksle, snart købe et eller andet for Pengene. Det tog da ogsaa en Ende med Forskrækkelse. Jeg blev nappet og sat fast, medens min Kollega under den storste Fare flygtede fra Flensborg.

\section{Lænker.}

En vis Kruse, som dengang var Politimester i Flensborg, optog Forhør over mig. Uagtet han ej blev overbevist om, at det var mig vitterligt, at Sedlerne var falske, erklærede han mig for Arrestant, hvorpaa han med de Ord: "Put ham ind!" gav en stor, skummel Karl Ordre til at fore mig i Fængsel. Jeg tænkte: "Det skal ellers ikke gaa saa let, som du mener.« Jeg fulgte vel den sorte Karl, som et Faar, der skal saavel klippes som flaas, men da han var kommen til den første Fængselsdør og satte 
Noglen i Arrestdøren, greb jeg saa hurtigt og stærkt i denne sorte og menneskelige Maskine, at han ramlede on i Rendestenen med et Rabalder, som om der var falden en gammel Hest, hvorpaa jeg brugte mine Ben saaledes, at Hælene sprang af mine Støvler. Da han havde faaet sig opsamlet, gav han sig til at brøle som en Løve, og da det var henimod Midnat, havde dette Brøl til Følge, at han tik Hjælp af Natvægtere. $\mathrm{Da}$ jeg havde sprunget et Stykke hen ad Gaden, blev jeg omringet af en Flok af dem. Jeg kastede til Side af dem, saa en fløj hen imod en Brønd. Men en anden huggede ind paa mig med dette forfærdelige Mordredskab, som kaldtes Morgenstjerne, og det fo'r med saa mange Pigger gennem alle mine Klæder ind i Siden paa mig, saa at Blodet lob frem af flere Aabninger. Alligevel fik jeg ogsaa haim kastet til Side, og da jeg ved denne Kamp havde slaaet mig igennem, fortsatte jeg min Flugt og søgte at komme bort fra Gaden. Ved mit Sidespring kom jeg ind $i$ en Have, hvor der var Ro, og jeg fandt det fornødent at trykke med Haanden ind $i$ Siden for at standse Blodet, da jeg ellers frygtede for at blive afmægtig af Blodtabet. For jeg tog mig i Vare, kom der imidlertid en stor Hund snusende hen imod mig, og bagefter den fulgte en Trop Politibetjente, bevæbnede med store Stokke, og dertil en større Trop Natvagtere med deres Pigkøller. Havde jeg haft en tilbørlig Knippel i min Haand, saa skulde jeg have slaaet mig gennem dem allesammen, thi den gode Gud har rundeligen forsynet mig med Kraft og Styrke. Vel var jeg ikke i Besiddelse af saadanne Kæmpekræfter som min Fader, men jeg var dog saa stærk, at naar jeg havde Fodfæste og holdt en Hest $i$ Halen, kunde den ikke rykke mig af Pletten, hvor meget man end piskede paa den, hvad mange har været Vidne til. Men nu stod jeg med de bare Hænder imod saa mange, som tilmed var vel bevæbnede. For ikke at faa Hjertet ud af Livet af Nattevægternes Pigkøller, maatte jeg derfor ovengive mig.

Jeg blev snart overbevist om, at Politimesteren hørte til den Slags Folk, som mere hadede Personerne end den onde Gerning, thi ellers havde han vel baaret Omsorg for, at Fangerne fik en bedre Pleje 
og ikke ladet en halv forrykt og hjerteløs Arrestforvarer ene og alene raade for de ulykkelige, af hvilke mangen en i Aar og Dag maatte friste Livet ved en Føde, hvoraf Vandet udgjorde Hovedbestanddelen.

Om Morgenen fik hver Fange nemlig en Potte Vand, der mere lignede Vaskevand end Thevand, som det skulde bære Navn af. The var det blevet fri for, af den Aarsag havde dette Vandslap vel faaet en Smule Kulør af nogle Draaber Mælk. Dertil tik hver Fange et tykt Stykke Brød, hvorpaa Smørret næsten var usynligt. Middagsmaden var nærmest Hundemad, saasom Kartofler, stegte i Vand, Grød, ligeledes kogt i Vand, Suppe, ligeledes Vand med nogle Kartofler og en lille, ringe Stump Kød. Men det allervarste var, at hvad Gud har skabt og undt baade gode og onde Menesker, nenlig Sol og frisk Luft, ogsaa var os nregtet. Derimod havile enhver Fange den allermodbydeligste stank tilligened andre trykkende Urenligheder, thi hver Fange maatte beholde al sin Urenlighed hos sig i en Til af otte Dage og stundom endog derover.

Under saadanne tyramniske Menneskeplagere máatte jeg, om jeg mindes ret, friste mit Liv i rigeligt 11 Uger, men jeg blev da ogsaa i denne Tid saa fordærvet og kraftlos, at jeg næsten ikke kunde staa paa mine Ben, og desuden blev Brystet saa daarligt, som om jeg havde den stærkeste Svindsot. Klagede man til Politimesteren over denne i enhver Henseende slette Behandling, havde han ingen Øre. Klagede man til Arrestforvareren, fik man til Svar, at sligt horte med til Straf. Gud ved, hvor meget han havde paa sin Samvittighed, endnu inden han blev Arrestforvarer. Thi han havde forhen været Underofficer, og til den Tid kunde en saadan behandle de stakkels Soldater, som de fandt for godt, saa at mangen en af dem derved mistede Livet eller Helbredet. Saadan tyrannisk Behandling af Soldaterne blev der først sat en Stopper for af vor nuværende milde og gode Konge Frederik den Syvende, som derved og paa anden Maade viser, at han har et aabent Øje og Hjerte for sit Folks Ve og Vel.

Jeg kom af og til i Forhør, hvori jeg maatte tage til det eneste Værge, jeg havde, nemlig Usandheder. 
Men det gik dermed som Sne, der forsvinder for Solen. Øvrigheden var nemlig ikke sen til at komme til mit Hus for at ransage efter, om der ikke fandtes noget, som kunde have været brugt ved Forfærdigelsen af Sedlerne. Det hverken gaves eller fandtes, men derimod faldt den Arlresse, under hvilken jeg havile skrevet til Møller paa Fyn, dem i Hænder, hvorpaa han og flere blev nappede og satte i Fængsel i Odense. Derfor blev jeg nu ogsaa taget ud af dette djævelske Fingsel og fort til Odense.

Denne Rejse gik saaledes for sig: Jeg blev lirnket paa Hander og Foduer og oven i Kabet lanket og laaset fast til Vognen af to Politibetjente, som skulde passe paa, at jeg ikke lob hort. Disse to Karle var de elendigste Kujoner, man kan tænke sig. Jeg kunde ikke rore mig det mindste, for Blodet straks foer dem til Hoverlet, og clesulen havde de den Tro, at en Fange kunde have saalan Forbindelse med Morkets Magter, at disse kunde puste Jernet itu paa ham. De sugte i saa Henseende at forske ud af mig, og jeg gav dem saa tvetydige Svar, at de kunde tro baade saa og saa. Netop som deres Tanker saaledes stod til mig og den oude, lob der tilfældigvis en Hare lige tæt for os over Vejen. Havde deres Angst været stor i Forvejen, blev den om muligt endnu starre. Jeg hørte dem i deres Flensborger Plattysk mumle on, at det var et slemt Tegn, da en Heks kunde paatage sig en Hares skikkelse, naar den havde noget i Sinde.

Jeg sad i Livsfare ved disse Tølperes dumme Overtro, thi Hestene var meget sky, saa hvis de tog Magten fra Kusken, maatte jeg slicles i Stykker, da jeg var lænket fast til Vognen.

Endelig blev jeg i Assens af de Flensborgske Menneskeplagere afleveret til det Odenseske Politi, hos hvilke jeg straks bemærkede, at de havde bedre Aand og Hịte end de, der nu havde pint mig i 2 Gange 24 Timer. Hvis jeg skulde have været længere under deres Behandling, havde jeg formodentlig mistet baade Haand og Fod, thi de Hundesjæle havde spændt Jernene saa haardt og stramt, at baade Haand og Foll var aldeles følelsesløse, og Fingrene var ganske blaa som Følge af, at Blodomlabet var standset. 